\title{
The Forgotten '45: Donald Dubh's Rebellion in an Archipelagic Context
}

\section{ABSTRACT}

The final rebellion of Donald Dubh, heir to the forfeited MacDonald lordship of the Isles, is usually examined within the context of Highland rebellions that occurred in the half century after forfeiture. The factors that motivated the Islesmen to rise in rebellion in 1545 were, however, multi-faceted and can only be fully understood by placing the rising in a wider context, which considers national and archipelagic events. The discussion that follows explores the reasons why the Islesmen, almost unanimously, entered into agreement with Henry VIII to attack Scotland from the west and why this endeavour failed. At the same time, the article highlights Henry's recognition of the strategic importance of the west which led him into alliance with Donald Dubh and his supporters.

Both the MacDonald lordship of the Isles and Clan Donald have been the subject of much attention, ranging from populist and romanticised history to scholarly analysis. Historical research has explored various aspects of the lordship and illuminated the role of Clan Donald within both Highland and wider Scottish society during the Middle Ages and early modern period. Dealt a crippling blow by James III's forfeiture of the earldom of Ross in 1475, the lordship of the Isles was forfeited too in 1493. In the ensuing decades of social and economic dislocation, the MacDonalds were further weakened by internal division. ${ }^{1}$ These problems found expression during the first half of the sixteenth century in various rebellions that broke out in the western Highlands and Isles, all of which were instigated by, led by, or connected to branches of Clan Donald. The last rebellion occurred in 1545, a few years after James $\mathrm{V}$ had annexed the lordship to the crown during his expedition to the Isles in $1540 .^{2}$ This rising was led by Donald Dubh, grandson

${ }^{1}$ Alison Cathcart, 'A spent force? The Clan Donald in the aftermath of 1493', in R.D. Oram, The Lordship of the Isles (Leiden, forthcoming). Some of the arguments advanced in this article have been revised and elaborated in the current article.

2 J.M.Thomson et al. (eds), Registrum Mangi Sigilli Regum Scotorum, 11 vols (Edinburgh, 1912-) $[R M S]$, iii, no. 2233; T. Thomson and C. Innes (eds), Acts of the Parliament

DR ALISON CATHCART is a Lecturer in History at the University of Strathclyde. She is grateful to Aonghas MacCoinnich, Martin MacGregor, Allan Macinnes, Roger Mason and Iain McDonald for commenting on various drafts of this paper. In addition, she wishes to acknowledge the financial assistance of the Society of Antiquaries of Scotland which allowed her to undertake research in Inveraray Castle Archives. 
of John MacDonald, fourth lord of the Isles, who had been forfeited in 1493. Apart from a brief spell in the opening years of the sixteenth century, when he was involved in a rebellion alongside his uncle, Torquil MacLeod of Lewis, Donald spent most of his life in captivity. ${ }^{3}$ His release, shortly after James V's death, coincided with several other events which precipitated the rebellion of 1545 .

Most discussions of these early sixteenth-century rebellions suggest that they aimed at lordship restoration. But the rebellions were complicated events in which several motives coalesced, none more so than in 1545. On the part of Donald Dubh, self-interest was paramount. He stood to regain the lands and lordship held by his grandfather, John, lord of the Isles. He also was offered English gold and military support to take revenge on the Gordons of Huntly and the Campbells of Argyll-two of the leading magnate families in Scotland-who had responsibility for law and order in the Highlands. The motives of other chiefs within the former lordship are, however, less certain. They stood to lose legal title to former lordship lands which they had received after 1493. James IV's grants and re-grants of land following the forfeiture had in some cases heightend rivalries within the former lordship. By 1545 some of these tensions still lingered, such as the dispute between the MacDonalds and MacLeods over Trotternish, in Skye, but in general it is doubtful that land disputes prompted rebellion. ${ }^{4}$ But did other chiefs, like Donald Dubh, also hope to restore the lordship?

Aside from the issue of the lordship, discussion of the rebellions has generally focused on their wider Scottish context. The cycle of rebellion and forfeiture fits into a wider historiographical narrative concerning the efforts of successive Stuart monarchs, from the late fifteenth to the early seventeenth centuries, to deal with their lawless and disorderly subjects in the Highlands and Islands. Moreover, successive Stewart monarchs had sought to maximise royal revenue from rents and taxes imposed on a region regarded as profitable. ${ }^{5}$ Just as financial considerations had been a significant factor in James III's forfeiture of the earldom of Ross in 1475, so too finance was a major concern of the 1540 Act of Annexation, which stated that:

${ }^{2}$ (Continued) of Scotland, 12 vols (Edinburgh, 1814-75), ii, 360-1, 404-5; K.M. Brown et al. (eds), Records of the Parliament of Scotland to 1707 (St Andrews, 2007-9), www.rps.ac.uk [RPS], 1540/12/26 (accessed 30 June 2012). The Act of Annexation extended to the 'landis and lordschipis of all his [the king's] Ilis, south and north; the tua Kintyris, with the castellis partening tharto and thare pertinentis; the landis and lordschip of Orknay and Yetland and the ilis pertening thereto and thare pertinentis'. 3 Torquil MacLeod of Lewis was married to Catherine, daughter of Colin Campbell, first earl of Argyll. See Stephen Boardman, The Campbells, 1250-1513 (Edinburgh, 2006), 283, 283 n. 114.

${ }^{4}$ Following the 1493 forfeiture, individual chiefs received charter for their lands from James IV. Subsequent revocations and re-grants fomented disputes between the former lordship clans. For details regarding Trotternish, see Donald Gregory, History of the Western Highlands and Isles of Scotland (Edinburgh, 1836), 130-1.

${ }^{5}$ Donald Munro's A Description of the Occidental i.e. Western Islands of Scotland (1549) remarked extensively on the rich, fertile land and good hunting and fishing. 
because the patrimonie of his croune and revenois therof being augmentit is the grett weill and proffitt baith to the kingis grace and all his liegis ... therfor it is thocht expedient that oure said sovirane lord ... suld annex to his crone for the honorabill support of his estate riale in all aventouris and caises, baith in weir and paice, sic landis and lordschipis as ar now presentlie in his handis that ar nocht annext of befor ... ${ }^{6}$

In the wake of James V's expedition to the Isles in 1540 an extensive survey was conducted of the land rentals newly acquired by the crown. This led to an increase in crown revenue. In 1542 John Mackenzie of Kintail raised practically double the sum of the previous return for Trotternish. ${ }^{7}$ Other areas, such as Jura, Colonsay and Ardnamurchan, returned an account for the first time. ${ }^{8}$ While the crown ostensibly intended to set lands 'to the auld possessouris, quhairbe it is easier to knaw the auld kyndlie tenentis', thereby suggesting that traditional patterns of land-ownership were retained, some chiefs were no doubt resentful of their new financial burdens. ${ }^{9}$ Royal intervention took other forms too. For example, the castle of Dunivaig, held for a long time by the MacDonalds of Dunivaig, was passed to Archibald Stewart, son of Ninian Stewart, chamberlain of Bute. ${ }^{10}$ Royal interference, in its disparate forms, presumably caused considerable discontent and these local grievances were inextricably intertwined with the rebellions.

The 1545 rebellion is, however, too often regarded as simply a local event focused around Donald Dubh. There is a wider context which must be examined too. ${ }^{11}$ The Islesmen entered into negotiations with Henry VIII and, under the leadership of Matthew Stewart, earl of Lennox, agreed to provide a force that would open another front in Henry's war against Scotland, attacking the estates of the Campbells and Gordons from the west. ${ }^{12}$ Ten or twelve ships were sent to Scotland

${ }^{6}$ RPS, 10 December 1540, 1540/12/26 (accessed 30 June 2012).

${ }^{7}$ John Stuart et al., The Exchequer Rolls of Scotland, 23 vols (Edinburgh, 1878-1908) [ER], xvi, 214, 283, 327; xvii, 18, 79, 218-19, 492-3; Jamie Cameron, James V: The Personal Rule, 1528-1542 (East Linton, 1998), 240. The annual rental of Trotternish from 1530 to 1539 was $£ 536$ s 7 d but $£ 400$ was returned for $1540-2$.

${ }^{8}$ ER, xvii, 539-41, 545-50, 556-7.

${ }^{9} E R$, xvii, $611-50$, at 650 .

${ }^{10}$ ER, xvii, 278-9.

11 Gordon Donaldson, Scotland: James V-James VII (Edinburgh, 1971), 72. More recent scholarship pays little attention to the event. See Steve Murdoch, Terror of the Seas? Scottish Maritime Warfare, 1513-1713 (Leiden, 2010), 49-50, 55; Marcus Merriman, The Rough Wooings: Mary Queen of Scots, 1542-1551 (East Linton, 2000), 150-1.

12 J.S. Brewer et al. (eds), Letters and Papers, Foreign and Domestic, of the Reign of Henry VIII, 22 vols (London, 1864-1932) [LEंP Henry VIII], xx (II), no. 42; Gregory, Western Highlands, 170, n. 2; K.A. Steer and J.W.M. Bannerman, Late Medieval Monumental Sculpture in the West Highlands (Edinburgh, 1997), 212-13. The Islesmen who signed the agreement with Henry included Hector MacLean of Duart, John Moidertach, captain of Clanranald, Rory MacLeod of Lewis, Alexander MacLeod of Dunvegan, Murdoch MacLean of Lochbuie, Angus MacDonald, brother of James MacDonald of Dunivaig, Allan MacLean of Torloisk, Archibald MacDonald, captain of the MacDonalds of Sleat, Alexander MacIan of Ardnamurchan, John MacLean of Coll, 'Gilliganau' MacNeill of Barra, Ewen MacKinnon of Strathordill, John MacQuarrie 
with the earls of Lennox and Ormond, along with the force of about 2,000 men from Ireland, plus an additional 300 mariners to man the ships. Donald Dubh had promised a force of 8,000 men and a fleet of 180 galleys (according to the council of Ireland). Thus, the total force could be estimated at around 10,000 men and 200 vessels. By comparison, in 1745 Charles Edward Stuart, the descendant of the Stuart royal line, arrived in Scotland with the support of Irish Jacobites but only two vessels, from France, one of which had to return having being damaged in an encounter with an English ship. When his army reached Edinburgh its ranks had swelled to 7,287 infantry and 300 horse. ${ }^{13}$ While there are limitations to the validity of the comparisons that can be drawn between the sixteenth and eighteenth centuries, the size of the two forces, and their military potential, were not dissimilar. Of course, the Jacobite army reached Derby and gained support in England and Ireland, thus transforming its historiographical reputation from the localised status which the 1545 rebellion has never escaped, even although it too should be interpreted in an archipelagic context.

The rebellion of 1545 was a by-product of Henry's efforts to force the Scots into accepting dynastic union with England. He sought to use armed forces from Scotland and his newly created kingdom of Ireland to support the English army already attacking Scotland from the south and east. James V had died in December 1542, shortly after the Scottish defeat at Solway Moss. He left a six-day old heir, Mary, thus creating an unexpected opportunity for Henry to forge union through the marriage of Mary to his son, Edward Tudor. In Scotland the royal minority and the religious factionalism that accompanied Henry's break with Rome brought about divisions that were exacerbated by the proposed dynastic union which would arise with the marriage of Mary Stewart to Edward Tudor. James Hamilton, second earl of Arran and heir presumptive to the throne, was a key figure in the minority administration. He supported dynastic union with England despite opposition from a procatholic and pro-French faction led by Cardinal David Beaton and Mary of Guise, widow of James V. Arran moved quickly to negotiate the marriage but the treaties of Greenwich, agreed on 1 July 1543, were denounced when presented to the Scottish parliament for ratification in December, by when Arran had realigned himself with Guise and Beaton. ${ }^{14}$ Henry then began his so-called 'rough wooing' of Scotland, intended to force the Scots into accepting dynastic union.

In the face of this onslaught the French provided assistance to the Scots. Mary of Guise, widow of James V, was a key figure in the

12 (Continued) of Ulva, John MacLean of Ardgour, Alexander Rannaldson of Glengarry, Allan Rannaldson of Knoydart, and Donald MacLean of Kingairloch.

${ }^{13}$ LEPP Henry VIII, xx (II), nos. 120, 819; D.G. White, 'Henry VIII's Irish kerne in France and Scotland, 1544-1545', Irish Sword 3 (1958) 213-25, at 223; Christopher Duffy, The '45 (London, 2003), 44-6, 206.

${ }^{14}$ Arran was the son of his father's second marriage and needed Beaton's support to secure legitimisation. See Amy Blakeway, 'The attempted divorce of James Hamilton, earl of Arran and governor of Scotland', Innes Review 61 (2010) 1-23. 
ruling administration and had care of the young queen. Having retained strong links with her Guise relations, she was determined that her daughter's marriage would strengthen ties with France. ${ }^{15}$ Indeed, Francis I was just as keen as Henry VIII to have the young queen married to his son. The French king had been watching events in Scotland closely for some time. In March 1543, shortly after James V's death, he had sent Matthew Stewart, earl of Lennox, to Scotland and in September Francis dispatched munitions and money, which Lennox stored in Dumbarton Castle. ${ }^{16}$ Although born and raised in Scotland, Lennox had been domiciled in France since 1532 and subsequently acquired denizenship there. Lennox now returned to Scotland with claims to the crown to rival those of the allegedly illegitimate Arran. ${ }^{17}$ When Arran reconciled himself with Beaton and Guise, Lennox's ambitions were seemingly thwarted. Moreover, Lennox's pursuit of his own interests, by means which included alliance with England, alarmed the French king. Jacques de le Brosse, the French ambassador, suggested that

in order to weaken the strength of ... the King of England, it was most needful... to draw away the said Earl of Lennox and to engage him to serve this realm and the King [of France].... in order to give the said Earl ways and means of doing so... the said lady and the said Cardinal... should give their consent, subject to the good pleasure of the Estates of the said realm, to his marriage with the young Queen of Scots. ${ }^{18}$

Guise may have supported this for a time but Lennox soon transferred his marital ambitions to her. ${ }^{19}$ When neither marriage proposal made headway Lennox finally alienated himself from both the French king and the Scottish government. ${ }^{20}$ He decided, instead, that his best

15 For further details see P.E. Ritchie, Mary of Guise in Scotland, 1548-1560: A Political Career (East Linton, 2002).

16 Gladys Dickinson (ed.), 'Discours des affaires du Royaume dEscosse depuys le jour que nous Jacques de le Brousse Seigneur dudict lieu Eschansson de Roy et Jacques Mesnaige Docteur es Droictz Seigneur de Caigny Conseiller dudict seigneur et ses Ambassadeurs audict Royaume sommes arrivez a Dombertran jusqua ce jour', in Two Missions of Jacques de la Brosse: An Account of the Affairs of Scotland in the Year 1543 and the Journal of the Siege of Leith, 1560, Scottish History Soc. (Edinburgh, 1942), 25; A.I. Cameron (ed.), The Scottish Correspondence of Mary of Lorraine, Scottish History Soc. (Edinburgh, 1927) [Scottish Correspondence], nos. 27-8; Merriman, Rough Wooings, 130, 133. Lennox had been appointed keeper of Dumbarton Castle for life in 1531.

17 The houses of Hamilton and Lennox were enemies. Sir James Hamilton of Finnart, illegitimate son of the first earl of Arran, and half-brother of the Governor, had killed Matthew's father in 1526 and exploited the revenues of the earldom of Lennox during Matthew's minority. Their relationship remained problematic and probably explains why Matthew went to France. As next in line to the throne of Scotland after the Hamiltons, that family regarded the house of Lennox as a threat.

18 'Discours', 29.

19 'Discours', 39 suggests this was supported by the French king as a way of keeping Lennox loyal; Robert Lindsay of Pitscottie, The Historie and Cronicles of Scotland, ed. A.J.G. Mackay, Scottish Text Soc., 3 vols (Edinburgh, 1899-1911), ii, 16-17.

20 'Discours', 29, 39. Henry had been trying to win over Lennox with promises of marriage too: see 'Discours', 19, 25. 
prospects lay with an English king keen to find allies amongst the lords of western and southern Scotland, who in turn might rebel in his support.

The Lennox estates were situated in the west of Scotland, around Loch Lomond; and the earl was also keeper of Dumbarton Castle. The castle was of enormous strategic importance and dominated the Clyde, the gateway to the west. ${ }^{21}$ Henry's naval forces could reach friendly soil and their invasion could cut Scotland in half, from Dumbarton in the west to Broughty Ferry in the east. ${ }^{22}$ The French were equally aware of the strategic importance of the west coast. As de la Brosse pointed out to Mary of Guise and the Cardinal in 1543:

the castle of Dumbarton was almost impregnable and... if the Earl of Lennox wished to hand it over to the King of England, the realm of Scotland would run the grave danger of being utterly lost, because the sea would be open to him [the King of England] to enter with his ships without any opposition and in such numbers as he wishes. And once landed he would be invincible unless a pitched battle were offered or famine ensued. ${ }^{23}$

For Henry, the advantages of an alliance with Lennox were obvious but the strategy was not without problem. The prevailing winds and tidal currents in the west meant that the route from England to Scotland via the east coast was much faster and less hazardous than that through the Irish Sea. ${ }^{24}$ Although English ships regularly sailed from London, Bristol and Chester with soldiers and victuals for Ireland, systematic patrolling of the Irish Sea remained limited, usually to periods of warfare or when the English sought to intercept shipping between France and Scotland.$^{25}$ Nevertheless, those who sought to avoid

${ }^{21}$ Joseph Bain (ed.), The Hamilton Papers: Letters and Papers illustrating the Political Relations of England and Scotland in the Sixteenth Century [Hamilton Papers], 2 vols (Edinburgh, 1890-92), ii, no. 4 [7]; Marcus Merriman, 'Stewart, Matthew, thirteenth or fourteenth earl of Lennox (1516-1571)', Oxford Dictionary of National Biography (Oxford, 2004; online edn, 2006), http://www.oxforddnb.com [Oxford DNB] (accessed 30 June 2012).

22 J.E.A. Dawson, Scotland Re-formed, 1489-1587 (Edinburgh, 2007), 171. This map shows the strength of the English forces in the south and east of Scotland and highlights how vulnerable Scotland was, should the English attack from the west. Henry may well have wanted to land his forces at Glasgow although Ayr was regarded at the time as suitable and where the forces of the west were traditionally mustered by the Scottish crown. The Jacobites in the eighteenth century also considered Ayr or Glasgow as suitable for a western invasion.

23 Dickinson (ed.), 'Discours', 29.

${ }^{24}$ For discussion of maritime activity on the east coast during this period see Murdoch, Terror of the Seas?, 42-59.

25 David Loades, The Tudor Navy: An Administrative, Political and Military History (Aldershot, 1992), 14, 45, 111, and esp. 144; N.A.M. Rodger, The Safeguard of the Sea: A Naval History of Britain, 660-1649 (London, 1997), 145-6, 186. There was some effort made to patrol the Irish waters in 1545. See H.C. Hamilton et al. (eds), Calendar of Sate Papers Relating to Ireland of the Reigns of Henry VIII, Edward VI, Mary and Elizabeth, 11 vols (London, 1860-1912) [CSPI], i, 72, no. 13. For much of this 
detection while en route between Scotland and France often journeyed through the Irish Sea. ${ }^{26}$ Lennox himself had arrived in Dumbarton in March 1543, having sailed, with munitions, armour and money, unmolested 'through an Irish Sea full of English warships'. ${ }^{27}$

The Irish Sea is a unique stretch of water with its own tidal regime, a result of the waters of the Atlantic entering the sea from both north and south. In the North Channel the Atlantic tides are forced into the narrow passage between Torr Head in Antrim and Kintyre in Argyll, making for strong tidal streams which can reach five knots. The streams are at their weakest between the Isle of Man and St John's Point on the Irish coast where, one-third of the way south through the Irish Sea, the tides from the north meet the Atlantic waters entering from the south. These waters extend much further into the Irish Sea because St George's Channel is three times broader than the North Channel. Thus, even with 'fair winds, a day's sail from south to north ... will be delayed by meeting an opposing tide at some point in the passage. ${ }^{28}$ In short, when relying on sail alone, even in favourable weather conditions, a journey through the Irish Sea would take longer than its distance would suggest. Indeed, the state papers are littered with references to delays in the passage to and from Ireland because of 'contrary winds' ${ }^{29}$

For various reasons, therefore, the English regarded the Irish Sea as a security risk. Tudor monarchs often feared invasion from the west because France or Spain could use Ireland as a launch-pad for attack. ${ }^{30}$ Likewise, James IV had been aware of the need to provide greater security around western coasts, especially in the wake of the 1493 forfeiture and the unrest that followed. He commenced a programme of ship building and repair work at Dumbarton in the winter of 1494-5 and in the following years he established royal garrisons and fortifications around the coast, at, for instance, Kilkerran, Tarbert and Ailsa Craig. ${ }^{31}$ After the outbreak of the rebellion in 1501

${ }^{25}$ (Continued) period the only shipping dedicated to the Irish Sea was the pinnace Popinjay. My thanks to Professor N.A.M. Rodger for discussing this with me.

${ }^{26}$ LE $\mathcal{P}$ P Henry VIII, xx (I), no. 1106. Mention is made of the Mary Willoughby, laden with wines and munitions, arriving in Leith having come by the Irish seas. Mary Stewart departed from Dumbarton in 1548, arriving undetected in France by the English.

${ }^{27}$ Merriman, 'Stewart, Matthew, earl of Lennox'. For further examples of shipping using the west coast see Murdoch, Terror of the Seas?, 45; Rodger, Safeguard of the Sea, 181.

${ }^{28}$ R.H. Buchanan, 'The Irish Sea: the geographical framework', in Michael McCaughan and John Appleby (eds), The Irish Sea: Aspects of Maritime History (Antrim, 1989), 3.

${ }^{29}$ For example see CSPI, i, 312, no. 91; 313, no. 2.

30 Shortly after Henry VII gained the English throne he faced several rebellions, two of which utilised Ireland as a base: J.D. Mackie, The Earlier Tudors, 1485-1558 (Oxford, 1952), 68-9, 116-34. In 1544 and 1545 Henry VIII was informed of rumours that the French intended to land Gerald Fitzgerald, heir to the forfeited Kildare estates, in Ireland to join in rebellion with the Scots against the English; see CSPI, i, 70 (nos. 47-8); 71 (no. 6).

${ }^{31}$ Norman Macdougall, James IV (Edinburgh, 1997), 104-5, 115-16. In 1494 James placed a royal garrison in Dunaverty Castle, on the southern tip of Kintyre, while in 1495 construction of a castle at Loch Kilkerran, near Campbeltown, commenced. 
James acknowledged that fortification of the Clyde was inadequate. Consequently, parliament recommended that the earl of Huntly should build a castle at Inverlochy on Loch Linnhe and that Stornoway should be reinforced, while Argyll was consulted about strengthening Dunaverty, Kilkerran and Cairn-na-Burgh. The construction of Saddell Castle and the proposal to transfer the see of Argyll from Lismore to Saddell Abbey in 1512 was part of this same strategy to fortify the west; ${ }^{32}$ and James $V$ reinforced defences, especially for the expedition of 1540 , when a royal garrison was established at Dunivaig and troops and canon left on Islay. ${ }^{33}$ It was to negate these defensive developments that Henry sought alliance with the military powers in the west. He turned initially, in December 1543, to Archibald, fourth earl of Argyll, regarded by the English as 'a man of wytte and force'. ${ }^{34}$

Argyll was married to Lady Helen Hamilton, daughter of the first earl of Arran and half-sister to the regent. Henry tried to pitch blood against marital kinship and Hugh Campbell of Loudoun, sheriff of Ayr, was enlisted to persuade Argyll of the benefits of an English alliance. ${ }^{35}$ With the prospect of Anglo-Scottish hostility looming, Loudoun argued that 'inclyning to [Henry's]... devocion, maye have noo small ayde... if incase they of the Ile shall chaunce to rebel' because the king had 'Irelande in suche subjection... whiche maye ayde hym at all tymes'. ${ }^{36}$ Henry sent 1,000 crowns to Loudon, to be offered as an annual pension to Argyll, while the earls of Huntly and Moray were also to be approached for an accommodation. ${ }^{37}$ Argyll did not take the bait. On 8 March 1544 Hertford asked Henry for 'x or xii shipps well eskypped and furnished, by the west sees, to do some annoyance to thErll of Argile'. ${ }^{38}$

Argyll's rejection of English overtures was not simply a sign of loyalty to his wife's kindred, the Hamiltons. In the fifteenth century the Campbells and the MacDonalds had co-existed largely harmoniously and, although Campbell influence in the west had grown, this had not

${ }^{31}$ (Continued) During his three naval expeditions of 1498 James visited his fortresses of Kilkerran and Tarbert, at the mouth of Clyde.

32 I.G. MacDonald, Clergy and Clansmen: The Diocese of Argyll, c.1189-1560 (Leiden, forthcoming).

33 Cameron, James V, 228-54.

${ }^{34}$ Hamilton Papers, ii, no. 131 [215]. Although a traditional Highland clan, the Campbell chief was an important national magnate too, at times holding offices of state. Sir Ralph Sadler, resident ambassador in Scotland at this time, must have encouraged Henry to approach Argyll. On 11 July 1543 he wrote that Argyll was 'well minded to the increase of the amity' between England and Scotland and 'to the uniting and conjunction of them' through the marriage of Mary and Edward. See Arthur Clifford (ed.), The State Papers and Letters of Sir Ralph Sadler, 3 vols (Edinburgh, 1806), i, 227.

35 The Campbells of Loudoun were a cadet branch of the main Campbell clan. Hugh Campbell, sheriff of Ayr, was still trying to win Scots over to Henry's side in 1545 . See LEP Henry VIII, xx (I), no. 438.

36 Hamilton Papers, ii, no. 131 [217]. See also nos. 135, 137-8.

37 Hamilton Papers, ii, no. 135 [221-2]. In December 1543 it was believed that the earls of Moray and Argyll would switch sides.

38 Hamilton Papers, ii, no. 183 [294]. 
brought the families into significant conflict. ${ }^{39}$ Donald Dubh had spent the early years of his life in the first earl of Argyll's custody at Innis Chonnell. Traditionally this has been interpreted as an 'imprisonment' but Argyll had not simply acted as a royal agent. ${ }^{40}$ Although the crown had relied heavily upon Argyll to suppress the early risings in the Isles, the earl displayed reluctance to take firm action, preferring negotiation rather than force in his dealings with the Islesmen. ${ }^{41}$ Moreover, while the crown took decisive action against the MacDonalds, successive earls built up ties with former lordship clans. Colin, third earl, collaborated with Lauchlan MacLean of Duart and Alexander MacLeod of Dunvegan in seeking to resolve the 1517 rebellion. ${ }^{42}$ At the same time connections between the Campbells and other clans were reinforced..$^{43}$ The first signs of MacDonald resentment towards the Campbells are only visible in 1529, when Alexander MacDonald of Dunivaig rebelled, and even this has been interpreted as merely a personal dispute about the MacIan inheritance. ${ }^{44}$ Nevertheless, in the wake of the rebellion, James $\mathrm{V}$ worked closely with MacDonald and Hector MacLean of Duart during the 1530s, deliberately keeping Argyll out of the west, a move which further questions the dominant historiography of Clan Donald's demise and Clan Campbell's rise. ${ }^{45}$ Nevertheless, by the time of James V's death Argyll had been rehabilitated into the political elite and, by taking his place in the minority government, the earl arguably saw his role as defender of Scottish, rather than local, regional or personal interests.

If Argyll's stance caused Henry frustration, a solution soon emerged. In January 1544 Lennox completed his volte-face and initiated negotiations with the English king. Lennox now sided with the pro-English, pro-union lords of the south-west, including Archibald Douglas, sixth earl of Angus, William Cunningham, third earl of Glencairn, and Gilbert Kennedy, third earl of Cassillis. Crucially for Henry, Lennox and his allies could provide much needed armed power

39 Colin, first earl, and Archibald, second earl, were appointed to positions within the government while Campbell influence at Iona continued. See Steer and Bannerman, Monumental Sculpture, 210-11; and Boardman, Campbells, 1-8.

40 See Boardman, Campbells, 278-83.

${ }^{41}$ Cathcart, 'A spent force?'; Boardman, Campbells, 278-83.

42 J.M. Thomson et al. (eds), Registrum Magni Sigilii Scotorum, 11 vols (Edinburgh, 1882-1914), i, no. 2873; R.K. Hannay (ed.), Acts of the Lords of Council in Public Affairs, 1510-1554 (Edinburgh, 1932), 78-82, 86-90.

43 J.M. Wormald, Lords and Men in Scotland: Bonds of Manrent, 1442-1603 (Edinburgh, 1985), App. A, 179 (no.8); Cosmo Innes (ed.), The Book of the Thanes of Cawdor: A Series of Papers Selected from the Charter Room at Cawdor, 1236-1742, Spalding Club (Edinburgh, 1859), 123-4, 128-9, 131, 133-41, 144-6; Steer and Bannerman, Monumental Sculpture, 211-12; Jane Dawson, "There is Nothing Like a Good Gossip": baptism, kinship and alliance in early modern Scotland', Review of Scottish Culture 15 (2002) 88-95, at 91; Cameron, James V, 228.

${ }^{44}$ For more on this, see Cameron, James $V$, 232-42, although compare with D.H. Caldwell, Islay, Jura and Colonsay: A Historical Guide (Edinburgh, 2011$), 82$.

45 Cameron, James V, 235-9; Alison Cathcart, 'James V, king of Scotland - and Ireland?' in Seán Duffy (ed.), The World of the Galloglass: Kings, Warlords and Warriors in Ireland and Scotland, 1200-1600 (Dublin, 2007), 127-40. 
in the west. During the next year Lennox used his Highland tenants to Henry's advantage and subsequently acted as middle-man between the king and the island chiefs.

It has been suggested that Henry's use of Islesmen was first proposed in a letter, dated $1542 / 3$, written by one John Elder, who signed himself 'a Redshank'. ${ }^{46}$ Elder was educated in Skye and Lewis before spending twelve years studying at St Andrews, Aberdeen and Glasgow. He ingratiated himself and the Islesmen with Henry by referring to the 'loue and fauour the valiant Yrishe lordes of Scotland, other wayes called the Reddshankes' had for the king because of how he had:

vsed, orderide, and dealide with the lordes of Irland, ther nyghboures ... perdonyng and forgiving theame ther offences and trespasses; creating of them, some erlis, some lordes, and some barons; rewarding theame more like princis then erlis and lordis, with gold, siluer, and riches; and sending theame home agane with gorgeous indumentis, and rich apparell. ${ }^{47}$

While asserting the loyalty of the Highlanders to the English king, Elder was, however, careful not to portray either himself or the Highlanders as disloyal subjects of the Scottish crown. He argued that if James V were still alive or had left 'a Prynce lawfully begotten of his body' then he 'wolde in no manner of wise presume to shaw and declair the privities of Scotlande to no Prynce Christen'. In other words, the absence of an adult monarch, combined with the 'miserable estate' that had resulted from the minority government's association with 'proud papisticall buschops', had pushed Elder and the Islesmen towards Henry. By disassociating the Islesmen from treason Elder was deploying a familiar tactic in Scotland. Minority government was something to which Scots were accustomed and disgruntled nobles often took the opportunity presented by a minority to make good losses incurred under the previous regime. Thus, rebellion was not directed against the crown, but rather against the ruling administration. Indeed, while the former lordship clans did not relish greater crown intervention, this was significantly more preferable than governmental intrusion by a relatively weak and divided administration. As Gregory argued, James V's death exposed the Highlands and Isles to 'domestic feuds between the powerful factions' at the heart of the minority government, whereas James V's adult reign had 'promised an assurance of a more lengthened period of repose than the Isles had hitherto enjoyed'. ${ }^{8}$

46 Gregory, Western Highlands, 155-6. Redshank was a term of limited usage in Scots and it is likely that Elder deployed a word familiar to the English. For further definitions see the Oxford English Dictionary, http://www.oed.com/ and the Dictionary of the Scots Language, http://www.dsl.ac.uk/dsl/. Elder was from Caithness, a Gaelic-speaking area at this time, which is why he referred to himself as a Redshank.

47 'A Proposal for uniting Scotland with England, addressed to King Henry VIII by John Elder, Clerke, a Redshank, 1542 or 1543', in D. Gregory and W.F. Skene (eds), Collectanea de Rebus Albanicis, Iona Club (Edinburgh, 1847), 23-32.

48 Gregory, Western Highlands, 149-50. 
This loyalty to the crown was reiterated by Rory MacAllister and Patrick MacLean, commissioners for Donald Dubh, in subsequent negotiations with Henry. ${ }^{49}$

It has been argued that Elder's protestant outlook explains his desire that the 'realms of England and of Scotlande may be joined in one' with Henry as 'superioure and kynge'. ${ }^{50}$ If so, Elder managed to intertwine his own views with the rather different motives of the Islesmen. For Elder their antagonism towards Argyll was because the earl was 'novrisshed and brought vp' by Cardinal Beaton and the bishops. ${ }^{51}$ Yet, one modern assessment reckoned that for the Islesmen 'religion ostensibly was not a factor'. ${ }^{52}$ Instead, the rent increases which followed the Act of Annexation caused resentment. So too had increased intervention in the region by the crown's agents, the Campbells and the Gordons. And perhaps too restoration of the lordship stimulated discontent. In negotiations with Henry, Donald was referred to as 'Lord of ye Ilis and Erll of Roiss', harking back to an era when the lordship was at its fullest extent, while the rebellion of 1545 was supported enthusiastically by former lordship clans. ${ }^{53}$ Of course, the reason for the Islesmen's discontent was probably not of any great interest to Henry. It did matter that many Islesmen had been alienated by James $\mathrm{V}$ and the minority administration; and that the malcontents were potential allies.

It was Sir Ralph Sadler, Henry's resident ambassador in Scotland, who recognised that Dumbarton and the Firth of Clyde were the 'kaye of the North'. ${ }^{54}$ This was perhaps reinforced by the 'plotte' (or map, now lost) that accompanied Elder's letter. ${ }^{55}$ In providing a map, Elder was pandering to an English king increasingly concerned with the

49 LEP Henry VIII, xx (I), no. 294 [135]; Rory MacAllister (brother of the captain of the Clanranald, bishop elect of the Isles and dean of Morvern) and Patrick MacLean (brother of MacLean of Duart, bailie of Icolmkill and justice clerk of the South Isles) were the commissioners appointed by Donald to negotiate with Henry.

${ }^{50}$ R.A. Mason, Kingship and the Commonweal: Political Thought in Renaissance and Reformation Scotland (East Linton, 1998), 252-3, where Elder is described as a protestant zealot; Marcus Merriman, 'James Henrisoun and 'Great Britain'; British Union and the Scottish Commonweal', in R.A. Mason (ed.), Scotland and England, 1286-1815 (Edinburgh, 1987), 89, 98 where [at 89] it is stated that Elder was forced to leave Dundee because of his reforming views; James Kirk, 'The Jacobean church in the Highlands, 1567-1625', in Loraine Maclean (ed.), The Seventeenth Century in the Highlands (Inverness, 1986), 27.

51 Opportunistically he had converted back to catholicism by 1555 , publishing on 1 January of that year The copie of a letter sent in to Scotlande, of the arivall and marryage of Philippe, prynce of Spaine to Marye quene of England, whereunto is added a brefe overture of Cardinall Poole ... for reconcilement to the catholyke churche. See Marcus Merriman, 'Elder, John (fl. 1533-1565)', Oxford DNB (accessed 30 June 2012).

52 Kirk, 'Jacobean church', 27.

53 LEP Henry VIII, xx (I), no. 1298; for motivations of the Islesmen in earlier risings see Cathcart, 'A spent force?'.

54 Hamilton Papers, ii, no. 4 [7].

55 Alexander Lindsay, A Rutter of the Scottish Seas (ca. 1540), edd. I.H. Adams and G. Fortune, National Maritime Museum (Greenwich, 1980), 38. It is suggested that Elder's map provided Lindsay with much-needed information regarding the north and west of Scotland and the western Isles. 
acquisition of geographical knowledge about Scotland while he planned for its invasion. ${ }^{56}$ Before the mid-sixteenth century most of England's navigational tracts were translations of continental manuscripts. Most maps were also of foreign origin. ${ }^{57}$ Although the best map-makers were Flemish, protestant French cosmographers and navigators had sought refuge in England and many found ready employment at Henry's court, where their knowledge was exploited eagerly. It has been suggested that by the end of his reign as many as sixty French mariners and pilots were in Henry's service. ${ }^{58}$ Unfortunately for the king, French cartographical knowledge of Scotland was focused primarily upon the east coast. Familiarity with the Irish Sea-awareness of its tides, currents and military potential-resided instead with the Islesmen. Although the English possessed galleys and pinnaces, their larger sailing vessels, constructed according to continental models, found the waters of the Irish Sea difficult to navigate. The Highland galley, or birlinn, descended from the Viking longship, was much more reliable and manoeuvrable in these waters. Clinker-built, preferably from oak, with a sharp stem and stern, a single mast and a rear or stern-rudder, such vessels had both oars and a square sail and were perfectly suited to the tide and weather conditions of the Irish Sea. The shallow draught allowed for easy manoeuvrability in sheltered coastal areas, inland rivers and sea lochs; but it was simultaneously deep enough to allow for safe crossing of a short but turbulent body of water. The combination of sail and oar was the key to successful raiding: in favourable weather sail was effective but the ability to revert to oar for a quick get-away, should conditions change, was highly advantageous.

Clan chiefs maintained their own birlinns and galleys, a source of strength that successive Scottish monarchs had sought to exploit for their own ends from as early as the time of Robert I (1306-29). ${ }^{59}$ Similarly, for many lords of Ayrshire and Galloway naval strength was of immense importance for commerce, fishing and defence. That in 1531 William Cunningham, master of Glencairn, offered to furnish five ships to assist King Christian II of Denmark illustrates the naval power of just one western lord. Cunningham's naval interests were evident on

56 Henry is likely to have asked Elder for a map. Elder may be the 'Skottishe docter learned in the lawe cyvell', mentioned by John Dudley, Viscount Lisle, in a letter to Henry VIII, dated at Alnwick Castle in December 1542. See Hamilton Papers, i, no. 255 [331].

57 E.G.R. Taylor, Tudor Geography, 1485-1583 (London, 1930), 4.

58 Taylor, Tudor Geography, 4, 13, 15-16; Lindsay, Rutter, 23, 28. Even The Rutter of the Sea (1528) was based on the first translation of Pierre Garcie's La routier de la mer (Rouen, 1502-10), although it is likely that the Scottish material in Lindsay's rutter was based on an earlier Scottish rutter.

59 Robert used the maritime strength of the Highlanders and Islesmen in 1315, when his brother, Edward, invaded Ireland. Galley service was regularly mentioned in the charters of the Campbells of Argyll. See, for example, Inveraray, Castle Archives, Argyll Transcripts, iv, 29 July 1533; 10 May 1550; Steve Boardman, 'The Campbells and charter lordship in Medieval Argyll', in Boardman and Ross (eds), Power in Medieval Scotland, 113-4. 
other occasions too. In 1538 he escorted the king's new bride, Mary of Guise, from France to Scotland and his son, Alexander, master of Kilmaurs, was appointed vice-admiral of James's expedition to the Isles in $1540 .{ }^{60}$ It is little wonder that external powers now courted men with such significant maritime power.

Care should be taken not to distinguish too greatly between Highlanders, Islesmen and south-western lords with whom Lennox also had close ties. ${ }^{61}$ Gaelic was spoken across a region stretching as far as Ireland which was bound by water and the communication which it facilitated. ${ }^{62}$ Lennox, his south-western allies and others too possessed estates that straddled what became known as the HighlandLowland divide. With both Gaelic and non-Gaelic tenants, landlords would have moved easily between the two areas. ${ }^{63}$ Moreover, both the Campbells and the MacDonalds maintained close connections with Ayrshire and Galloway families. ${ }^{64}$ Before 1493 the lords of the Isles held the lands of Greenan, in Ayrshire, where their main tenants were the Davidsons. ${ }^{65}$ The main line of Campbells had marital connections with the Montgomery family; ${ }^{66}$ and in 1536 Elizabeth, daughter of

${ }^{60}$ Denis Hay (ed), Letters of James $V$ (Edinburgh, 1954), 186-7, 198-9, 364; RSS, ii, no. 4631; LESP Henry VIII, xv, no. 634; R.K. Hannay (ed.), Acts of the Lords of Council in Public Affairs, 1501-1554: Selections from the Acta Dominorum Concilii (Edinburgh, 1932), 504; ER, xvii, 625, 626, 630-1; D.E.R. Watt and A.L. Murray, Fasti ecclesiae Scoticanae medii aevi ad annum 1638 (Edinburgh, 2003), 27; RMS, iii, nos. 345, 2816; Thomas Dickson and J.B. Paul et al. (eds), Account of the Lord High Treasurer of Scotland, 13 vols (Edinburgh, 1877-1978), vii, 400.

${ }^{61}$ Writing about the fifteenth century, Boardman refers to the last group by the contemporary designation of 'westland' lords. The 'westland' included Cunningham, Lanarkshire and probably other areas around the Clyde, such as Kyle and Renfrewshire. The 'lords of the westland' engaged in occasional political and military activity in Argyll, the Clyde islands and Hebrides. They often acted in association with Gaelic lords from the latter areas. See Stephen Boardman, "Pillars of the community": Campbell lordship and architectural patronage in the fifteenth century', in R.D. Oram and Geoffrey Stell (eds), Lordship and Architecture in Medieval and Renaissance Scotland (Edinburgh, 2005), 123-59, at 138, n. 45.

${ }^{62}$ Aonghas MacCoinnich, 'Where and how was Gaelic written in late medieval and early modern Scotland? Orthographic practices and cultural identities', Scottish Gaelic Studies 24 (2008) 309-56, at 314-15, n. 15.

63 Gregory, Western Highlands, 166-9; Michael Brown, 'Earldom and kindred: the Lennox and its earls, 1200-1458', in Boardman and Ross (eds), Power in Medieval Scotland, 201-24; MacCoinnich, 'Where and how was Gaelic written?' The division between east and west was much more blurred in the sixteenth century than today. For Gaelic poetry from the Lennox in the early sixteenth century, see Wilson McLeod and Meg Bateman (eds), Duanaire na Sracaire. Songbook of the Pillagers: Anthology of Scotland's Gaelic Verse to 1600 (Edinburgh, 2007), 266-7, 366-71.

${ }^{64}$ Jean Munro and R.W. Munro (eds), Acts of the Lord of the Isles, Scottish History Soc. (Edinburgh, 1986), xxxviii, 96, 298.

65 Acts of the Lords of the Isles, nos. A40, A68; Norman Macdougall, 'Achilles' heel? The earldom of Ross, the lordship of the Isles and the Stewart kings, 1449-1507', in E.J. Cowan and R.A. McDonald (eds), Alba: Celtic Scotland in the Medieval Era (East Linton, 2000), 265-6.

66 Macdougall, James IV, 97-9. These contacts extended into the ecclesiastical sphere. Montgomery and Cunningham clergy were related through marriage to the earls of Argyll and the Campbells of Loudoun. See MacDonald, Clergy and Clansmen. 
John Campbell of West Loudoun, married William Cunningham, third earl of Glencairn. ${ }^{67}$ The third earl had risen to prominence because of his service in the west, which had included acting as the king's commissioner and surveyor of crown lands in Kintyre in the early 1540s. Others performed similar service: Archibald Stewart of Bute was, for example, made captain of the castle of Dunivaig on Islay. ${ }^{68}$

In March 1544 Lennox, Angus, Cassillis and Glencairn sent commissioners to treat at Carlisle with Thomas, first Baron Wharton, and Sir Robert Bowes, commissioners appointed by Henry VIII. ${ }^{69}$ Before agreement was reached Henry acquired 'cause to be dissuaded': Angus was not to be included because of his 'manifest appearance of untruth' and Cassillis had switched sides, returning to Arran's fold. ${ }^{70}$ Lennox and Glencairn remained, however, useful. On 17 May 1544 they acknowledged Henry as 'King Director and Protector of Scotland'; ${ }^{71}$ and on 28 May, leaving Glencairn at Dumbarton, Lennox sailed to London where the agreement reached at Carlisle was formalised on 26 June. ${ }^{72}$ In addition, Lennox agreed to deliver Dumbarton Castle, Rothesay Castle and the isle of Bute to the English king, and to serve Henry 'as his subject, against all who impugn his right, title and authority in Scotland or offend him in any dominions in his possession, or to which he has any title'. In return Henry granted Lennox the marriage of Margaret Douglas, the king's niece, and agreed that when he gained 'the direction and rule of Scotland' Lennox would be appointed governor. ${ }^{73}$ On 29 June the marriage took place at St James's Palace and on 10 July Lennox became an English subject. ${ }^{74}$

Later in July 1544 henry equipped Lennox with sixteen ships and 600 soldiers for an expedition to secure the Dumbarton garrison. Lennox took Rothesay Castle on Bute before reaching Dumbarton although securing his own castle was not straightforward. While Lennox had been in England Mary of Guise had won Glencairn over and plans were laid to take Lennox prisoner when he returned. On arrival Lennox became suspicious and withdrew before he could be apprehended. ${ }^{75}$ Although unable to take the castle he did not leave

${ }^{67}$ H.L. MacQueen and John Simmons, 'Cunningham family (per. c.1340-1631)', Oxford DNB (accessed 30 June 2012.

68 M. Livingstone (ed.), Registrum Secreti Sigilli Regum Scotorum, 1488-1580 (Edinburgh, 1908-) [RSS], ii, no. 4628.

${ }^{69}$ LEFP Henry VIII, xix (I), no. 243 The commissioners sent to treat with Wharton and Bowes were Mr John Penven, a chaplain, and Mr Thomas Bishop, Lennox's secretary.

${ }^{70}$ LESP Henry VIII, xix (I), no. 337 [220].

${ }^{71}$ LEP Henry VIII, xix (I), no. 522. The commissioners who agreed this indenture in May were the earl of Glencairn himself, Robert, bishop elect of Caithness, brother of the earl of Lennox, Thomas Bishop and Hugh Cunningham.

72 LEP Henry VIII, xix (I), no. 779.

${ }^{73}$ LESP Henry VIII, xix (I), nos. 337, 779. Margaret Douglas was the daughter of Margaret Tudor, widow of James IV, and Archibald Douglas, sixth earl of Angus.

74 Merriman, 'Stewart, Matthew, earl of Lennox'.

75 For Glencairn's re-alignment and peace with Mary of Guise see Scottish Correspondence, nos. 76-7, 84 . 
Scotland frustrated. Prior to his departure from London, the queen's council at Hampton Court informed Lennox: 'at your commeng home, you shuld fynde M'Farlane and the hieghland men redy to join with you'. ${ }^{76}$ The Macfarlanes were tenants of Lennox, inhabiting lands around Arrochar. ${ }^{77}$ They were presumably among over one hundred Highlanders who joined Lennox's force before he left Dumbarton. Rather than retreat to England in defeat, he caused havoc along the shore of the Clyde, attacking Dunoon and wasting other parts of Argyll, including Kintyre. ${ }^{78}$

Although Glencairn, Cassillis and Angus wavered in their allegiance to Henry, the ruling administration in Scotland was not complacent about the threat which Lennox posed. More alarmingly still, Donald Dubh had gained his liberty in uncertain circumstances. Sadler made no mention of Donald's release when he recorded on 19 August 1543 that Arran had released 'certayne Irishe men ... long prisoners in the castellis of Edinburgh and Dunbar' and sent them 'home onlye of policye... to hold the said erle of Argyll occupied'. ${ }^{79}$ The suggestion is that their release was arranged by Arran and other enemies of Argyll, including Glencairn, Cassillis and Angus, who resented Argyll's refusal to join with the English faction. ${ }^{80}$ Indeed, Glencairn may also have harboured personal grievances against Argyll. Glencairn had acquired lands in Kintyre from James $\mathrm{V}$ and in 1543 his son, the master of Kilmaurs, was appointed as governor of Kintyre for one year. ${ }^{81}$ This would not have been welcomed by Argyll who, in October 1542, was confirmed as justice, sheriff, coroner and chamberlain of the lands and lordship of Kintyre and Knapdale. In early 1543 Argyll was granted Dunaverty Castle, further expanding Campbell influence in the region and frustrating intentions Glencairn may have harboured for his family's expansion into Kintyre. ${ }^{82}$

If the chiefs and hostages were liberated before Donald Dubh, this may explain the account in the 'Book of Clanranald' which stated that

76 Hamilton Papers, ii, no. 296. This was information provided by Glencairn who, at that time, was allied to Mary of Guise against Lennox.

77 W.C. Mackenzie, The Highlands and Isles of Scotland: A Historical Survey (Edinburgh, 1949), 141-2, 142 n. 20, where it is argued that Lennox had considerable 'Highland assistance'(Cosmo Innes and J.B. Brichan (eds), Origines Parochiales Scotiae, Bannatyne Club, 2 vols (Edinburgh, 1850-55), ii, pt 1). The Macfarlanes, similar to other Lennox kindreds descended from the comital line, looked to the earls as natural lords and superiors. Usually known as the MacFarlanes of Arrochar, residing on the northern shore of Loch Long, they had maritime access to the Firth of Clyde.

78 LEP Henry VIII, xix (I), no. 813; xix (II), no. 186; Hamilton Papers, ii, no. 317; Donaldson, Scotland, 70; Gregory, Western Highlands, 164-7.

79 Edinburgh, National Library of Scotland [NLS], Adv. MS. 33.3.10, fo. 232v; Sadler Papers, i, 266-7.

${ }^{80}$ Hamilton Papers, ii, no. 135 [222].

${ }^{81} E R$, xvii, 626, 630-1; RSS, ii, no. 4631.

82 Relations between Glencairn and Argyll deteriorated further when Argyll (among others) received a commission of April 1544 to take Glencairn's 'housse and strenthis' and keep them in the crown's name (Inveraray, Castle Archives, Letters E Papers of the Family of Argyll (Edinburgh, 1875), ii, nos. 26-7). 
Donald was liberated by a 'Fenian exploit' on the part of the men of Glencoe. ${ }^{83}$ Donald had, in other words, escaped against the will of the government. ${ }^{84}$ Other evidence suggests, however, that Donald was released at the same time as the other prisoners. James Stewart, earl of Moray, wrote to Mary of Guise from Dingwall on 2 November 1543 stating that 'the cuntre men is uncertane of pourpois ... of the fredome of the Lord of Ilis'. ${ }^{85}$ But if Donald had been released with the other prisoners in August 1543, he could not have agreed a truce with Argyll in March 1543. ${ }^{86}$ Donald's movements remain, then, uncertain and little is heard of his activities until late $1544 .^{87}$

News of Donald's rebellious activity was broken to Mary of Guise on 24 October 1544, when she was informed by the countess of Moray that 'the Lord of the Ilis is broken forth'. ${ }^{88}$ Bannerman interpreted this as Donald launching an attack on Ross, which suggests that following release he had headed north. ${ }^{89}$ In 1501, when released from Innis Chonnell, Donald had made for his uncle, Torquil MacLeod of Lewis, and in 1544 Donald seemingly once again headed for sympathetic kin and friends. News of the unrest spread quickly. In December 1544 Henry VIII's envoy, Alexander Crichton, laird of Brunston, had enquired of Francis Talbot, fifth earl of Shrewsbury, then serving on the Borders and negotiating with individual Scots, 'geif Donnald of the Illis keipis his Yuill' at Inverness. ${ }^{90}$ On 31 December 1544 Stephen Vaughan, Henry's financial agent in Antwerp, noted that a 'Scot told me here that he heard say that there should be risen a new king in Scotland out of the Scottyshe Irysshe'. ${ }^{91}$ Such rumours were given credence by Sir Anthony St Leger, lord deputy of Ireland, who in February 1545 reported to the council in London that:

the Scots will send one McOnell, of the Isles, with many Wilde Scots to land in the North of this land, where Young Geralde [Fitzgerald], by aid of the Frenchmen, will arrive. ${ }^{92}$

83 'The Book of Clanranald', 163. Donald may have been assisted in his escape after the release of those imprisoned by James $\mathrm{V}$.

${ }^{84}$ LESP Henry VIII, xx (II), 294 [185]. Boardman, Campbells, 282, 282 n. 112, which demonstrates that Gregory's account of Donald Dubh (see Western Highlands, 95-6, 155) stems from a 'conflation of the Sleat and Clanranald account'.

85 Scottish Correspondence, no. 34.

86 NLS, Adv. MS. 33.3.10, fo. 154r; Sadler Papers, i, 192; LE PP Henry VIII, xx (I), no. 664.

87 'Discours', 17-19 mentions that in 1543 'two lords of the Isles, near Dumbarton, had five or six thousand wild men who each day carried out raids and wrought havoc by fire or other ways, on the lands and subjects of the Earl of Argyll, in Scotland, with whom they were at feud'. I would argue that this, and Sadler's reference to the 'erle of the Isles' (n.101 above), does not relate to Donald Dubh but another member of the MacDonalds. Other comments by Sadler in his papers suggest that at times he is referring to events in 1544 despite them being dated to 1543. My thanks to Dr Amy Blakeway for discussing this point with me.

${ }^{88}$ LEP Henry VIII, xix (II), App. 12.

${ }^{89}$ Steer and Bannerman, Monumental Sculpture, 212, n. 15.

90 Hamilton Papers, ii, no. 391 [536]; LESP Henry VIII, xix (II), no. 790.

91 LEP Henry VIII, xix (II), no. 795.

${ }^{92}$ LEP Henry VIII, xx (I), no. 273. 
Gerald, the remaining heir to the forfeited Kildare earldom in Ireland, had been sent to France a few years earlier for his safety following the failure of the Geraldine rebellion and the subsequent execution of all those involved. ${ }^{93}$ In response to the rumours St Leger asked the king for ships to defend the waters of the north of Ireland against both the French and the Islesmen. The fear was of Irish rebellion, led by the exiled heir to the forfeited Kildare earldom, supported by Islesmen, led by the heir to the forfeited lordship of the Isles. An attack of this magnitude might have proven fatal to Henry's ambitions, not least since he had lost the support of the lords of the south-west.

These concerns were alleviated by the arrival at court of Patrick MacLean, a messenger dispatched from 'the Lord of the Isles'. MacLean had been initially sent to Lennox, since December 1544 in Carlisle, where he could "more advance our affairs... to practise with the Scots ... "sow devision amonge them" or at least to get intelligence'. ${ }^{94}$ After discussion with Lennox, MacLean headed south. It was, therefore, in early 1545 that direct communication between Henry and the Islesmen commenced. On 12 March Henry told Lennox to do 'anything for the advancement of the King's affairs,' sending 800 crowns as a reward for Donald although it was left to Lennox's discretion when the money should be delivered.$^{95}$ In the interim, waiting for a response from the English king, Donald agreed to a truce with Argyll and Huntly, to last until 1 May 1545, and he even promised to visit the queen at Stirling. ${ }^{96}$ On discovering this, the English expressed concern and Lennox was advised on 27 March not to hand over the 800 crowns until sure that Donald would 'remayne firme and constant' in his alliance with Henry. ${ }^{97}$ Shortly after reports reached London that the truce had expired and that Argyll and Donald Dubh were both preparing to attack each other. ${ }^{98}$

As well as preparing to harry the lands of Argyll and Huntly, Donald had been cultivating his connections with Hugh O'Neill, head of the mighty Tyrone kindred, as a means of demonstrating his loyalty to the English. On 6 May St Leger informed the council in London that:

the earl of Tyrone, being now at Dublin, declares that McConell has desired him to petition the King to accept him to his service. Tyrone says that McConell is mortal enemy to the earl of Argyle... [who] since the king's death is enlarged and grown to great power'. ${ }^{99}$

${ }^{93}$ For more on this see S.G. Ellis, 'The Kildare rebellion and the early Henrician Reformation', Historical Journal 19 (1976) 807-30; M.A. Lyons, Gearóid Óg, The Ninth Earl of Kildare (Dublin, 1988); Cathcart, 'James V'; Mícheál Ó Siochrú, 'Foreign involvement in the revolt of Silken Thomas, 1534-5', Proceedings of the Royal Irish Academy 96 C:2 (1996) 49-66.

94 LEP Henry VIII, xix (II), no. 719

95 LE'P Henry VIII, xx (I), nos. 285, 347-8. Patrick MacLean was brother of MacLean of Duart, bailie of Icolmkill and justice clerk of the South Isles and see n. 49, above.

96 LEFP Henry VIII, xx (I), no. 382; Hamilton Papers, ii, no. 428 [583].

97 Hamilton Papers, ii, no. 432.

${ }^{98}$ LEPP Henry VIII, xx (I), nos. 642, 664.

99 LEP Henry VIII, xx (I), no. 665. 
While the Islesmen may have caused problems for Argyll and Huntly in recent months, this is the first specific indication of MacDonald resentment towards Argyll. Donald singled the earl out as an enemy, along with 'all that were friends to the Scottish king that dead is'. This statement harks back to John Elder's letter which emphasised that the Islesmen were not disloyal to the Scottish crown but rather to the ruling administration. They were loyal to monarchical authority-but since James $\mathrm{V}$ was dead, they now looked to Henry.

Negotiations progressed rapidly. On 28 July 1545 a commission was drawn up at 'Ellencarne', the island in Loch Ballygrant on Islay, in which Donald Dubh, styled 'Lord of ye Ilis and Erll of Roiss', elected two plenipotentiaries to negotiate with Henry. ${ }^{100}$ The commission was subscribed by all the island chiefs except James MacDonald of Dunivaig and Torquil MacNeill of Gigha. Torquil was an old man and his absence and that of his, Niall, is often overlooked. ${ }^{101}$ MacDonald's brother, Angus, was present and is usually regarded as a proxy for James. This should not be accepted without question. Angus and James grew up separately and Angus may have joined the rebellion regardless of his brother's opposition or neutrality. James had been brought up at court and was married to Agnes Campbell, Argyll's sister. James had sought security of his Scottish lands through his marital connections but his younger sibling sought to obtain title from Henry for his lands in the Glens of Antrim. While the two brothers had a similar aim, that of securing title to land, they were working to very different agenda, a possible pre-cursor to the split in the clan that would occur later in the sixteenth century. ${ }^{102}$

By early August 1545 the island chiefs, with a force of 4,000 Scots, were at Carrickfergus on the east Antrim coast, a place 'more propice for them to serve the King against the Scots than any port in their own land'. ${ }^{103}$ Here they swore an oath of allegiance to Henry and honed the finer details of the agreement. Throughout the negotiations the Islesmen added legitimacy to their cause by consistently referring to Lennox as 'true governor' and 'second person' of Scotland, thereby attempting to discredit the ruling administration. ${ }^{104}$ In addition, Donald Dubh and the Islesmen agreed to support the marriage of Mary and Edward and to keep Argyll and Huntly militarily engaged. ${ }^{105}$

${ }^{100}$ LESP Henry VIII, xx (I), no. 1298; Caldwell, Islay, 83. The island belonged to the MacLeans of Duart and in many ways resembled the Council Isle at Finlaggan. For the commissioners see n. 49, above.

101 See, however, Steer and Bannerman, Monumental Sculpture, 212-13.

102 George Hill, An Historical Account of the Macdonnells of Antrim (Belfast, 1873), 41-5.

103 LEFP Henry VIII, xx (II), nos. 120-1. Carrickfergus was familiar to Scots and only a short sail across the North Channel. The failure to capture Dumbarton Castle meant it was safer for the force to assemble in Carrickfergus. In Scotland it would have been watched closely as the privy council was well aware of the dealings between Donald Dubh and Henry.

${ }^{104}$ LESP Henry VIII, xix (II), no. 1298; xx (II), nos. 40-1.

105 LESP Henry VIII, xx (I), no. 642 (2 May 1545), regarding the 'earl of Ellis' who will keep Huntly and Argyll 'occupied' and showing that Donald Dubh took action against 
This would be achieved through the provision of a force of 8,000 Scotsmen, half at Carrickfergus while the remainder kept watch on events in Scotland. Henry would assist by sending 2,000 kerne and galloglass under leadership of the earl of Ormond. ${ }^{106}$ Their objective in Scotland 'besides generall annoyances to be doon in burning herieng and spoiling' was 'thannoyaunce of the said Erll of Argiles countrey'. ${ }^{107}$ In addition, Lennox was to be furnished with a cannon, artillery and munitions, while 3,000 of the Scots forces were to receive a wage for two months. ${ }^{108}$

This was easier said than done. Despite Henry's orders, the Irish council in Dublin was in no position to carry his instructions out. It continually requested money from England with which to pay the Scots and early in October 1545, with Lennox on his way to Ireland to join the expedition, the council stated that it was not ready to provide men, ships, arms, or money. ${ }^{109}$ In future it requested 'longer notice of the king's wish to use the service of Irishmen whose captains must keep their countries furnished with men against the neighbours, for this land is not like England'. ${ }^{110}$ The delay in assembling the provisions and force from Ireland was too great for the Islesmen who returned to Scotland to await the arrival of Lennox and the Irish. They were wary of lengthy absence from Scotland and anxious to protect their own lands. But the unity of the Islesmen was under threat too. Henry's payments had not been distributed 'to the satisfaction of all' and following disagreement the force disbanded. ${ }^{111}$ Lennox finally arrived in Ireland on 10 October 1545 by when the Islesmen had returned home. ${ }^{12}$ Lennox wrote to Donald Dubh, telling him to prepare for rebellion, but it was not until 15 November that, accompanied by Ormond and the force of 400

105 (Continued) Argyll immediately after the end of the truce. According to ibid., xx (I), no. 1106 [544] (4 July 1545) the English suggested sending 3-4,000 men to aid the Islesmen who were to occupy Huntly and Argyll. Otherwise, a large army would be needed in the Borders 'for all Scotland will be there by reason of encouragements of the Frenchmen and the French king's promises'.

106 Kerne was the name given to Irish forces, while galloglass refers to Scots permanently settled in Ireland under the pay of Irish and English-Irish lords.

${ }^{107}$ LEFP Henry VIII, xx (II), no. 295; Nicholas Maclean-Bristol, Warriors and Priests: The History of the Clan MacLean, 1300-1570 (East Linton, 1995), 119.

108 For details of the negotiations between Donald Dubh and Henry, see LEFP Henry VIII, xx (I), no. 1298; xx (II), nos. 40-2, 120-1, 198, 291-5, 304-5. Lennox needed munitions because those sent by the French king had been stored in Dumbarton Castle. Having failed to recapture the castle Lennox no longer had access to its resources.

${ }^{109}$ LEFP Henry VIII, xx (II), no. 562.

${ }^{110}$ LEFP Henry VIII, xx (II), no. 562. This suggests that perhaps it was the Old English who provided support for Donald's rebellion. LESP Henry VIII, xix (I), no. 261 indicates that in March 1544 Henry had ordered 1,000 kerne to be sent to England to fight against the Scots.

111 'Book of the Clanranald', ii, 167.

112 LEFP Henry VIII, xix (II), no. 770; xx (I), nos. 129, 295, 562. It would appear that Lennox departed for the Borders at the end of December but he was certainly in Carlisle by February 1544/5. 
galloglass, 1,550 Irish kerne (fifty with half hakes) and fifty archers, he sailed to Scotland. ${ }^{13}$

It is unlikely that the invasion force headed for Dumbarton. ${ }^{114}$ On 5 October 1545 Argyll had been granted Glenfruin, Rosneath and the Isle of Inchmurrin in Loch Lomond. ${ }^{115}$ These lands, lying within the earldom of Lennox, were in crown hands following the recent forfeiture of Lennox. Granting the Rosneath peninsula to Argyll, for the earl's service in defence of the kingdom against the English enemy, was a strategic move. Lennox no longer had clear access through the Firth of Clyde to Dumbarton Castle, which, by this time, was in the hands of the pro-French administration. It is possible the fleet headed for Ayr or Bute instead. ${ }^{116}$ It is, however, not clear what happened when Lennox, Ormond and the Irish force arrived in Scotland but efforts to reunite the Islesmen were unsuccessful. ${ }^{117}$ Donald Dubh failed in amassing another army to continue with the plan. Subsequently, he returned to Ireland and died at Drogheda 'of a fever of five nights'. ${ }^{118}$ James MacDonald of Dunivaig grasped the opportunity and, writing from Ardnamurchan on 24 January 1546, he asked Henry for two or three ships and money. MacAllister and Maclean, Donald Dubh's commissioners who were still in Dublin, presented his letters to the lord deputy and council in February but the offer received no response. ${ }^{119}$ The moment for rebellion had passed.

Lennox's recall to the Borders is often advanced as the explanation for why the rebellion of 1545 petered out. ${ }^{120}$ Lennox had been in Carlisle since December 1544 although in the weeks preceding the rebellion he appears to have been frequently on the move. In late August 1545 MacLean and MacAllister, in London, requested a meeting

113 LEFP Henry VIII, xx (II), nos. 562, 662, 676, 796; CSPI, i, 73 (nos. 23, 25).

${ }^{114}$ Holinshed's Chronicles of England, Scotland and Ireland, 6 vols (London, 1807-8), vi, 315-16 suggests that storms blew the fleet, anchored at Olderfleet, a castle on the coast not far from Carrickfergus, to Dumbarton and then 'gratious clemencie' blew the fleet safely back to Ireland.

115 RMS, iii, no. 3173.

116 LEPP Henry VIII, xx (II), no. 676.

117 LESP Henry VIII, xx (II), no. 819. The Irish council had not been optimistic that Lennox would be able to reunite the force.

118 'The Book of Clanranald', 167, states he left no child; but Gregory, Western Highlands, 176 and MacDonald, Clan Donald, i, 386 suggest that he left an illegitimate son in the care of Henry. On 25 April 1551 Archibald, earl of Argyll, received a charter from Arran, then governor, regarding Rory MacLeod of Lewis who 'hies laitlie takin ane pupill barne... and haldes him in nurssing \& maintenna[n]ce of purpose \& mynd to make \& set him forwart at the utremost of his power tobe lord of ye Ilis \& using yat na[me] and draw samony as he may ... gif ye shoud be sufferit, it wilbe occasioun of gret truble \& inconveinets to ws and [com]mon wele of orwe realme'. There is no further evidence that this 'barne' was a child of Donald Dubh (Inveraray Castle Archives, bundle 1083).

119 CSPI, i, 73 (no. 29); 74 (no. 31). In May of that year MacAllastair and MacLean, still in Dublin, were trying to return to Scotland while according to John Roche Dascent (ed.), Acts of the Privy Council of England: New Series, 46 vols (London, 1860-1964), i, 483, MacLean died in Dublin soon after this.

${ }^{120}$ Murdoch, Terror of the Seas?, 55. 
with the earl and for him to be sent to Ireland. ${ }^{121}$ Lennox still had an important intermediary role between the Islesmen and Henry. But while significant, his absence was not the only reason for the failure to amalgamate the force of Irish and Scots. Donald Dubh too was unable to maintain unity among the Islesmen. The kerne and gallowglass who were to join the Islesmen were to be chosen "out of the "most wild and savage sort" ... whose absence should do good rather than hurt'. ${ }^{122}$ Assembling this army at short notice proved difficult and, as St Leger informed the English privy council, the 'journey into Scotland is strange to the men of this land'; it was compounded by 'the bruit of slaying of their countrymen in the late conflict on the Borders of Scotland'. ${ }^{123}$ Irish troops had been sent to the Borders previously, in 1544, and although Hertford initially regarded them as "unrewly and farr out of good order' he subsequently commended their 'good service in this journey'. ${ }^{124}$ He noted also that the Irish had 'moche dred of the Scottes' and disliked their custom of killing enemies rather than taking them prisoner. ${ }^{125}$ This reluctance of the Irish to fight alongside Donald Dubh, in alliance with Henry against the Scots and Argyll, is intriguing. Several Scottish clans, notably the MacDonalds, MacLeans and Campbells, maintained Irish ties. Perhaps Argyll (and/or James MacDonald of Dunivaig), exercised greater leverage over the galloglass than Donald Dubh. ${ }^{126}$ It is also possible that Irish reluctance was ideological (since many Irish continued to oppose Tudor authority in Ireland) or that it was simply an expression of reluctance to leave home. Payment of wages may have enticed many to serve in the Borders but reports filtering back of inadequate food supplies would have been a very real disincentive to further engagement. Irish lords, of course, also needed to maintain a fighting force on their own lands.

Absence from home was not something that the Islesmen too would long tolerate. Given the war with England and widespread unrest in the west Highlands and Isles, delays at Carrickfergus were not ideal. For the Islesmen wages were also a thorny issue. The western Isles maintained a body of fighting men who were not 'labourers of ye ground'. ${ }^{127}$ These men were permitted to 'byde firth ane haill zeir as ofttimes it happins... ony... p[ar]ticular Islands has to do w[i]t $[\mathrm{h}]$

121 LEPP Henry VIII, xx (II), no. 196.

122 LEP Henry VIII, xx (II), 305. Their 'absence' refers to their absence from Ireland.

123 LEP Henry VIII, xx (II), 562.

${ }^{124}$ Hamilton Papers, ii, nos. 212, 219, 231, 244, 261; Appendix no. 22.

125 Hamilton Papers, ii, nos. 261, 327. This was also the custom of the Borders. The Scots did not receive wages, so would not spare victuals for prisoners. By September 1544 the English reported the Irish were raiding Scottish towns for corn.

126 The English were aware of connections between the O'Donnells of Tyrconnell and Argyll; see CSPI, i, 65 (no. 2); 67 (no. 18). Despite the growing resentment towards Campbell expansion the earl of Argyll continued to be a very powerful and influential figure in the politics of the west Highlands and Isles.

127 NLS, Adv. MS. 31.2.6., which states that the total number of men maintained for warfare was 6,000; W.F. Skene, Celtic Scotland: A History of Ancient Alban (Edinburgh, 
Irland or neighbo[u]rs' ${ }^{128}$ Thus, Highlanders and Islesmen had a long record of fighting in the wars of the native Irish but they did not do so without pay. Although Henry had promised wages for 3,000 men for two months, the Islesmen had already spent one month at Carrickfergus before returning home. It is difficult to corroborate the claim that they disbanded because of internal squabbles over the distribution of the English money but it is clear that money was a factor. During the negotiations between Henry and Donald Dubh the issue of financial payment loomed large. ${ }^{129}$ Aggrieved by recent rent increases, the Islesmen were not in a position to maintain themselves for a sustained absence from home. The Islesmen were not, however, motivated purely by mercenary ends.

Restoration of the lordship was an aspiration of many from the forfeiture of 1493 until the mid-seventeenth century. ${ }^{130}$ This was more than just nostalgia for a supposed golden age. It was a very real expression of the grievances of the Islesmen. The only extant contemporary source from the region, was written by Donald Monro, a priest at Snizort, in Skye, in 1526 and then rector of Briagh na h-Aoidhe, near Stornoway, in the late 1540s. Monro's account was the first to refer to the council of the Isles which is assumed to have met at Finlaggan. The fourteen members of the council supposedly 'decernit, decreitit and gave suits furth upon all debaitable matters according to the Laws', even if the 'Lord were at his hunting or at ony uther games'. ${ }^{131}$ Considering the correlation between the signatories of the 'Ellencarne' commission of 28 July 1545 and the council described by Monro, it has been suggested that Monro revealed less about how the lordship operated during the fifteenth century and more about the realities of the mid-sixteenth century; Monro's council comprised 'the leaders of Hebridean kindreds, mindful and jealous of their own status, rights and privileges'. ${ }^{132}$ He described how these Islesmen had governed the region since the forfeiture: 'thair was great peace and welth in the Iles throw the ministration of justice'. ${ }^{133}$

127 (Continued) 1880), iii, 428-40. For more details of this see D.H. Caldwell, 'The seapower of the western isles of Scotland in the late medieval period' (forthcoming). My thanks to Dr Caldwell for allowing me to see a copy of this article prior to publication.

128 NLS, Adv. MS. 31.2.6., fo. 31r.

${ }^{129}$ LEFP Henry VIII, xx (I), no. 865. It was not just the Islesmen who Henry sought to win over through the promise of money. See also LEFP Henry VIII, xix (I), nos. 337, 522, 779 .

130 Aonghas MacCoinnich, "His spirit was given only to warre': conflict and identity in the Scottish Gáidhealtachd, c.1580-c.1630' in Steve Murdoch and Andrew Mackillop (eds), Fighting for Identity: Scottish Military Experience, c.1550-1900 (Leiden, 2002), 148.

131 A Description of the Occidental i.e. Western Islands of Scotland by Mr Donald Monro who travelled through many of them in Anno 1549 (Edinburgh, 1999), 310.

132 Stephen Boardman, 'The lordship of the Isles', in Seán Duffy and Susan Foran (eds), The English Isles: Cultural Transmission and Political Conflict in Britain and Ireland, 1100-1500 (Dublin, forthcoming). My thanks to Dr Boardman for allowing me to see a copy of this article prior to publication.

133 Description of the Occidental Isles, 310. 
This peace, wealth and justice had been maintained despite more intensive crown intervention after 1493. James IV had enacted legislation to ensure the observance of Scots law in the Isles; successive earls of Argyll and Huntly had been used to enforce government policy; and there had been consistent efforts to maximise crown revenues in the region. ${ }^{134}$ All of this came without representation. The 'Ellencarne' signatories were, therefore, a disaffected 'political community', supporting Donald Dubh's rising because it offered an opportunity to express grievance at a time when such actions were not, as they asserted, a rebellion against the Scottish crown. ${ }^{135}$

That the rebellion of the Islesmen was aimed at the minority government and the earl of Argyll in particular was oft reiterated, as was the assertion that the Islesmen remained loyal subjects of the Scottish crown. O'Neill claimed that Argyll was Donald Dubh's 'mortal enemy' and Donald's own letters emphasised that the Islesmen had consistently opposed 'enemies to the realm of Scotland'. ${ }^{136}$ In their final agreement with Henry the Islesmen were engaged specifically against Huntly and Argyll. This is understandable from an English perspective, as keeping Argyll and Huntly occupied on their estates in the south-west and northeast respectively would be advantageous for the English army on the Borders. ${ }^{137}$ It is less clear why Argyll was singled out by Donald Dubh. The Campbells of Argyll were not the hated figures they would become a century later.

Criticism of Argyll echoed John Elder's letter to Henry VIII of 1542/3. Elder's aim was, however, to distinguish Argyll from other 'valiaunt Yrishe lordes of Scotland'. ${ }^{138}$ Subsequently, Argyll's role in government, his refusal to join with the pro-English party, his kinship ties to Arran and his decision not to join Gaels in the west combined to ensure that he became the main focus for resentment on the part of those in rebellion. Still, the western Highlands and Isles were not homogenous and Argyll was not alone in his refusal to rebel. While the chiefs of most lordship clans supported the rising, James MacDonald of Dunivaig and the Glens was non-committal, even although he assumed leadership of the movement, without any great success, following Donald Dubh's death. ${ }^{139}$ While Donald had his own agenda, it is likely that other Highland chiefs carried personal ambitions too. Lordship restoration provided only a fragile unity and individual concerns with

${ }^{134}$ RPS, 1504/3/45 (accessed 30 June 2012).

135 Boardman, 'Lordship of the Isles'.

136 LEFP Henry VIII, xx (I), no. 273; xx (II), no. 294 [135].

137 LEPP Henry VIII, xx (II), no. 1106 [544].

138 'A Proposal for uniting Scotland with England, addressed to King Henry VIII by John Elder, Clerke, a Redshank, 1542 or 1543'.

${ }^{139}$ LEFP Henry VIII, xxi (I), nos. 114, 138, 219, 275; CSPI, i, 73-4 (no. 29) suggests that James was recognised by some as heir to the lordship. 
land and local, rather than national, issues, was evident amongst the lords of the south-west too. ${ }^{140}$

Several lords of the south-west had allied with Henry because they genuinely supported closer union with England through the marriage of Mary and Edward. Some, like Huntly, opposed Henry because they were committed to the catholic cause and did not want to see protestantism encouraged in Scotland. Religious views did not always shape political allegiances. Although Argyll was catholic, his loyalty to the Arran administration derived from close kinship ties with the regent, a desire to protect Campbell estates and a concern to defend wider Scottish interests in the face of English aggression. Lennox, also catholic (despite his promises of conversion to protestantism in 1544), allied with Henry because of self-interest. ${ }^{141}$ His personal ambitions in Scotland were thwarted by Arran's appointment as governor and, alienated from the French king, Lennox trod the well-worn path to London taken by many disgruntled Scots. Self-interest remained a powerful force.

It has been argued that 'the Scottish nobles... in the long run... were true to Scottish interests. The spirit of nationality was more powerful than the disintegrating forces of selfishness. ${ }^{142}$ But this view is hard to sustain in the face of such factionalism and vacillation on the part of those involved. For example, Archibald Douglas, sixth earl of Angus, who had been driven into exile by James V in 1529, signed a contract in 1532 recognising Henry VIII as supreme lord of Scotland. A long-term ally of the English king, he supported dynastic union through marriage but changed to support the Scottish side late in 1544 and continued this attachment until his death. No doubt his switch was encouraged by the remissions which Mary of Guise granted to several earls, including Cassillis and Glencairn, as well as Angus, in November 1544. Ultimately, however, Angus's move was motivated by his desire to protect his interests in the south-west: alliance with the winning side was the surest way to achieve this. ${ }^{143}$ Glencairn supported Henry's campaign because he favoured religious reform but he changed sides constantly, eventually dying a pensioner of France in March 1548. ${ }^{144}$ While a developing sense of national identity can be detected

140 Despite Henry's attempt to persuade them to 'work so substancially, as your affections and good willes to the avauncement of our affayres'. See Hamilton Papers, ii, no. 69 [114].

141 Given Lennox's catholicism and Henry's reluctant protestantism, Elder's connection with both makes his anti-Catholic epistle appear somewhat disingenuous. See Murdoch, Terror of the Seas?, 51, where Lennox is described as 'newly protestant'.

142 Scottish Correspondence, p. xxv.

143 Merriman, Rough Wooings, 142-3; Gregory, Western Highlands, 165; Marcus Merriman, 'Douglas, Archibald, sixth earl of Angus (c.1489-1557)', Oxford DNB (accessed 30 June 2012). Merriman uses the example of the Douglas earls of Angus to illustrate this.

144 Scottish Correspondence, p. xxv, n. 1; nos. 26, 29, 35, 76-7, 84; LEFP Henry VIII, xix (I), nos. 243, 522, 779; xix (II), nos. 185, 302; xx (I), no. 1106; M.H.B. Sanderson, 'Cunningham, William, third earl of Glencairn (d. 1548)', Oxford DNB (accessed 30 June 2012). 
throughout this period, identity remained multi-faceted, conditioned by political, religious, regional, dynastic and personal factors, as well as by nationalism. ${ }^{145}$

Henry's efforts to conquer Scotland had the potential to redraw the political map of Britain and Ireland. Rather than indulge in counterfactual speculations, we can, however, best understand his failure by analysing the origin of his quest. The Henrician Reformation had resulted in a complete realignment of English foreign policy. While Henry had been troubled by unrest in Ireland before the $1530 \mathrm{~s}$, he could no longer afford to let it rumble on. Foreign, catholic intervention in Ireland posed a direct threat to England's security. On his northern border Henry had tolerated his nephew, James V, interfering in his new Irish kingdom and growing in stature on the European stage, even although other European powers sought to use James in order to irritate the English king. ${ }^{146}$ After James's death, Arran's flirtation with protestantism was promising but short-lived. The denunciation of the treaties of Greenwich and Arran's reconciliation with Beaton meant a catholic Scotland continued to pose a threat to the English king. The invasion that followed was not simply an attempt to persuade the Scots forcibly into agreeing to the dynastic union. It was also, in accordance with tradition, intended to secure England's northern border. ${ }^{147}$

It was set against this wider imperative that Henry recognized the importance of the west, and the Firth of Clyde and Dumbarton Castle in particular. He received regular reports of French shipping sailing through the Irish Sea and Clyde estuary and realized the potential for attacking Scotland from the west. ${ }^{148}$ Through negotiation and circumstance Henry gathered allies in the west, who possessed knowledge of tides and navigation and who could provide substantial military and maritime support on both sides of the Clyde. The extent of his support in the west of Scotland explained Henry's belief that the west, Stirling and Leith were the keys to Scotland. But his western allies comprised various groups, motivated by different factors. Henry managed to bring this disparate force together in 1545 but he was an opportunist who at times needed encouragement to act. He did not have a well-formulated or carefully-planned archipelagic agenda and he had no coherent naval and military outlook. Although Henry arguably laid the foundations of English naval strength, his efforts were not the result of an 'instinctive appreciation of the importance of sea power' or, indeed, of any grand plan for English supremacy of the seas. They were born of necessity. ${ }^{149}$ Indeed, it is doubtful if Henry fully thought through

145 M.H.B. Sanderson, Ayrshire and the Reformation: People and Change, 1490-1600 (East Linton, 1997), 59-60.

146 Cathcart, 'James V, king of Scotland', 132-7.

147 Hiram Morgan, 'British policies before the British state', in Brendan Bradshaw and John Morrill (eds), The British Problem, c.1534-1707: State Formation in the Atlantic Archipelago (Basingstoke, 1996), 73; J.J. Scarisbrick, Henry VIII (London, 1968), 424.

148 For example, see LEP Henry VIII, xx (I), no. 665.

149 Rodgers, Safeguard of the Seas, 165. 
the implications of co-ordinating his forces in the three kingdoms and he did not try to exploit the full maritime power of the western Isles. He allowed the opportunity of 1545 to slip through his fingers because he thought in terms of a land war, using naval forces simply to transport men and supplies, and because there were weightier distractions on the continent. Unable to give Scotland his full attention, Henry was slow to harness support, causing some to waver in their loyalty and others to change sides. His lack of strategic planning explains why his force disintegrated at a crucial moment. He failed to see that such a force would readily default to local and regional concerns regarding land and self-preservation if momentum was not maintained. Indeed, had Henry devoted more time and planning to 1545, contrary to Donaldson's opinion, it might well have been in the West Highlands that the fates of Scotland, England and Ireland were decided. ${ }^{150}$

${ }^{150}$ Donaldson (Scotland, 72) argued that 'the fate of Scotland was not to be determined in the West Highlands'. 